\title{
CHEMICKÁ ANALÝZA BETÓNOVÝCH TRÁMCOV VYSTAVENÝCH AGRESÍVNEMU PROSTREDIU
}

\author{
CHEMICAL ANALYSYS OF CONCRETE BEAMS EXPOSED TO AGGRESSIVE \\ ENVIRONMENTS
}

\author{
Ing. Iveta Hegedüsová, Ph.D., Doc. Ing. Sergej Priganc, Ph.D.
}

\begin{abstract}
ABSTRAKT
V článku sú prezentované výsledky chemickej analýzy betónových trámcov dlhodobo vystavených mikroklíme pol'nohospodárskeho objektu. Chemický rozbor sa urobil po 27 rokoch expozície v agresívnom prostredí za účelom posúdenia množstva nepriaznivých chemických látok v betónovom prvku a ich dopad na jeho degradáciu. Betónové trámce boli vystavené vplyvu agresívneho prostredia počas dlhého časového úseku.
\end{abstract}

Kl'účové slová: betónové trámce, chemická analýza, chloridy, sírany, dusičnany, amónne soli.

\section{ABSTRACT}

The article presents chemical analysis results of concrete beams exposed to microclimate conditions of an agricultural structure for a long time. The chemical analysis has been made after 27 years of the aggressive environment exposure to evaluate the amount of unfavourable chemical substances in a concrete element and their impact onto its degradation. The concrete beams were exposed to the aggressive environment influence for a long period of time.

Key words: concrete beams, chemical analysis, chlorides, sulfates, nitrates, ammonium salts.

\section{1 ÚVOD}

Problematika súčasných existujúcich pol'nohospodárskych objektov na Slovensku, popísaná v [1], poukazuje na nutnost' eliminácie degradačných vplyvov na životnost' betónovej konštrukcie týchto objektov. Pri ich výstavbe vplyv maštal'ného prostredia nebol dostatočne popísaný a ani ošetrený vtedajšími platnými normami, preto v súčasnosti vysoký stupeň ich degradácie poukazuje na možné oslabenie nosnej funkcie. V minulosti sa vykonal chemický rozbor vzoriek odobratých $\mathrm{z}$ degradovaných stropných panelov, výsledky sú uvedené $\mathrm{v}$ [1] a [2] a tieto poznatky sú doplnené o výsledky z rozboru betónových trámcov, ktoré boli v objekte uložené v svetlíkovom priestore, aby boli vystavené rovnakým podmienkam ako stropné panely. Chemický rozbor bol zameraný na zistenie obsahu škodlivých látok v betónovej konštrukcii (amónne soli, chloridové ióny, sírany, dusičnany) a alkalitu, vzhl’adom na dlhodobý vplyv agresívneho maštal’ného prostredia a následnú degradáciu týchto betónových prvkov.

\section{PRÍPRAVA EXPERIMENTU}

Betónové trámce o rozmere 40 x 40 x 160 mm boli účelovo uložené do priestoru svetlíka strešnej konštrukcie v objekte kravína K-174 v Liptovskom Ondreji v roku 1987. Cielom uloženia vzoriek v objekte bolo získanie údajov o vplyve agresívneho prostredia na betónovú konštrukciu. Trámce boli v objekte uložené 27 rokov, predpokladalo sa, že po dlhšom časovom úseku uskladnenia budú mat' 
tieto vzorky zaujímavú výpovednú hodnotu z hladiska poskytnutia cenných poznatkov o degradácii betónu vplyvom agresívneho prostredia na základe chemickej analýzy.

Trámce boli z objektu K-174 prevezené a uskladnené v suchom prostredí laboratória, kde boli roztriedené a označené. Z hl'adiska triedenia do skupín sa zohl'adňoval vzhl'ad, miera poškodenia, povrchová štruktúra jednotlivých vzoriek. Dôležitým parametrom pre zatriedenie do skupín bolo aj pôvodné značenie na vzorkách, ktoré naznačovalo, ktoré vzorky pochádzajú z rovnakej zámesi betónu. Pôvodná receptúra týchto betónových trámcov sa totiž nezachovala, informácia z dostupného zdroja hovorí, že dokumentácia bola v pôvodnom podniku skartovaná. Avšak vykonali sa pevnostné skúšky [1], ktoré preukázali, že ide o vysokopevnostný betón.

Triedením vzniklo dvanást' skupín vzoriek, označených značkou 1a až 12b (Obr. 1). Väčšia čast' vzoriek vykazovala tuhú štruktúru (1a - 5b), menšia čast' mala štruktúru pórovitú (6a -7c, 12a - 12b), vzorky s označením od 1a - 7c a vzorky 12a - 12b boli bez výstuže, vzorky s označením od $8 \mathrm{a}-11 \mathrm{~b}$ boli vystužené jedným prútom o priemere $12 \mathrm{~mm}$. Z vizuálneho hladiska vzorky nevykazovali viditel'né poškodenie na ich povrchu, o čom svedčí aj fotodokumentácia, avšak sfarbenie povrchu a zápach naznačovali chemické znečistenie.
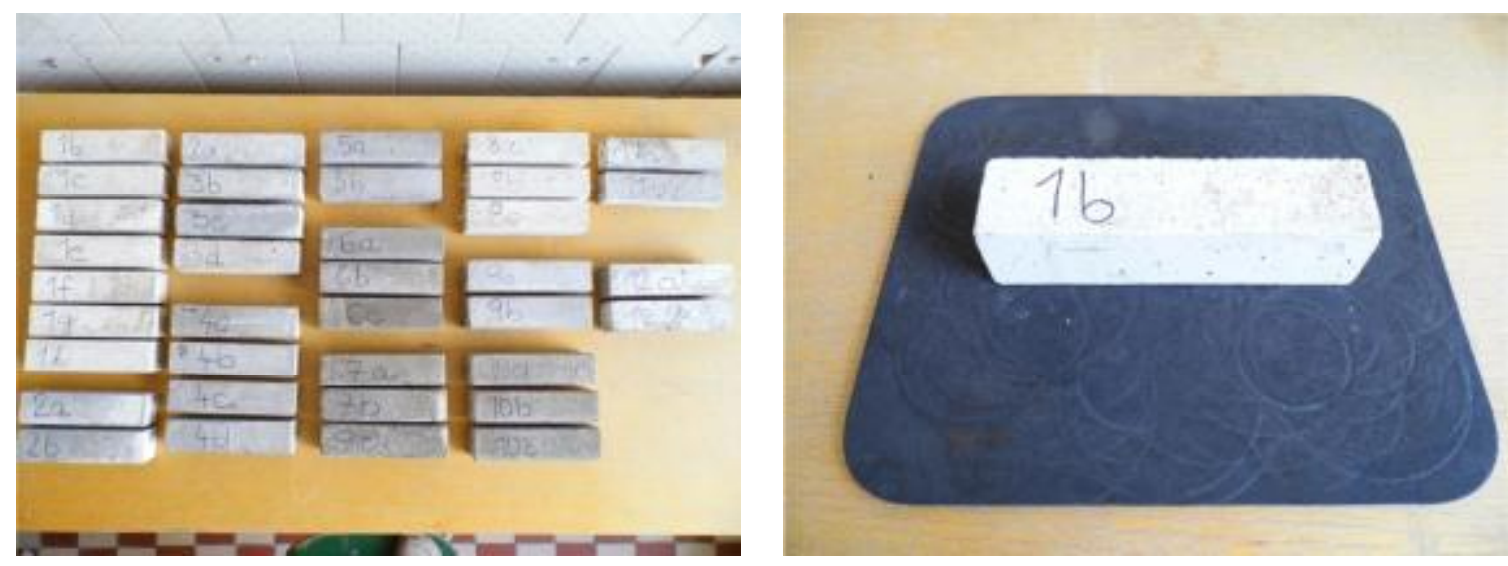

Obr. 1 Triedenie vzoriek do skupín

\section{CHEMICKÁ ANALÝZA}

Chemická analýza, jej ciel' a náplň, je popísaná v [1]. Štandardnými postupmi sa získali poznatky o obsahu škodlivých látok v trámcoch, čo umožnilo posúdit' nepriaznivý vplyv týchto látok na kvalitu betónu. Aj u betónových trámcov (rovnako ako u stropných panelov) bol použitý fenolftaleínový test a u vzoriek, po spracovaní na výluhy, sa stanovila alkalita na základe merania hodnôt pH. Stanovili sa aj koncentrácie chloridových iónov $\left[-\mathrm{Cl}^{-}\right]$, dusičnanov $\left[-\mathrm{NO}_{3}{ }^{-}\right]$, amónnych solí $\left[-\mathrm{NH}_{4}^{+}\right]$a semikvantitatívne sa posudzovala aj prítomnost' síranov $\left[-\mathrm{SO}_{4}{ }^{2-}\right]$.

\subsection{Príprava a meranie vzoriek}

Betónové trámce sa podrobili v prvom kroku pevnostným skúškam, čo je popísané v [2]. Zostatkové vzorky trámcov s pôvodným označením 1a - 12b sa do chemického laboratória previezli v mikroténových vreckách s rovnakým označením. V laboratóriu boli rozdelené do dvoch skupín, na skupinu vzoriek trámcov bez výstuže (1a - 7c a 12a - 12b), spolu 27 vzoriek, na skupinu vzoriek trámcov s výstužou ( $8 \mathrm{a}-11 \mathrm{~b})$, spolu 10 vzoriek. Z každej vzorky sa jej čast' použila na fenolftaleínový test a zvyšok vzorky sa použil na pomletie. Príprava výluhov (Obr. 2) a meranie vzorek je popísané v [1]. 

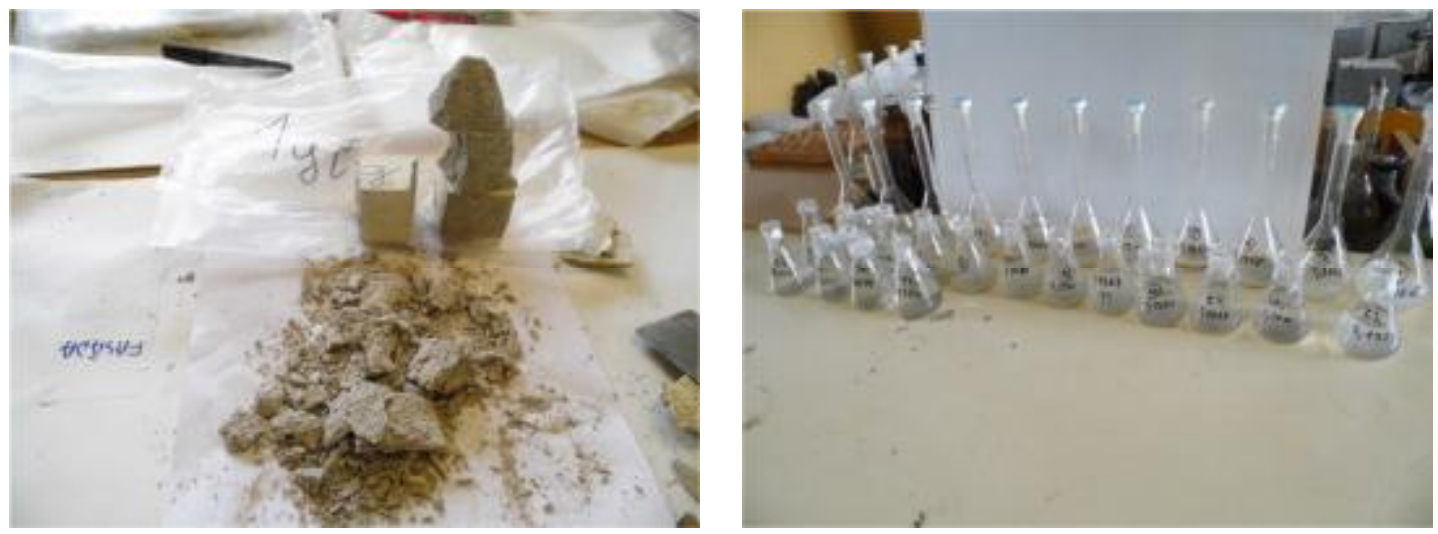

Obr. 2 Príprava výluhov ku skúškam

Po ukončení chemických skúšok sa namerané hodnoty spracovali, koncentrácie uvedené v mg/l sa prepočítali na percentuálny obsah a výsledky sa zaznamenali v Tab. 1 a 2 . Na Obr. 3 a 4 je pre porovnanie priemerného obsahu chemických látok $\mathrm{v}$ jednotlivých skupinách uvedené grafické znázornenie pre skupiny trámcov bez výstuže a grafické znázornenie pre skupiny trámcov s výstužou.

\begin{tabular}{|c|c|c|c|c|c|}
\hline $\begin{array}{c}\text { Ozn. } \\
\text { vzorky }\end{array}$ & $\overline{\mathrm{pH}[-]}$ & $\begin{array}{c}\text { chloridy } \\
{[\%]}\end{array}$ & $\begin{array}{c}\text { dusičnany } \\
{[\%]}\end{array}$ & $\begin{array}{c}\text { sírany } \\
\text { semikvant. }\end{array}$ & $\begin{array}{l}\text { amónne } \\
\text { soli [\%] }\end{array}$ \\
\hline $1 \mathrm{a}$ & 9,82 & 0,161 & 0,062 & ++ & 0,049 \\
\hline $1 \mathrm{~b}$ & 10,37 & 0,128 & 0,058 & +++ & 0,047 \\
\hline $1 \mathrm{c}$ & 10,50 & 0,103 & 0,055 & +++ & 0,044 \\
\hline $1 d$ & 10,02 & 0,114 & 0,113 & ++ & 0,045 \\
\hline $1 \mathrm{e}$ & 9,20 & 0,092 & 0,058 & + & 0,048 \\
\hline 1f & 9,16 & 0,099 & 0,060 & +++ & 0,044 \\
\hline $1 \mathrm{~g}$ & 9,38 & 0,104 & 0,054 & ++ & 0,043 \\
\hline $1 \mathrm{~h}$ & 9,01 & 0,073 & 0,059 & ++ & 0,047 \\
\hline $2 a$ & 9,12 & 0,598 & 0,058 & + & 0,046 \\
\hline $2 b$ & 9,48 & 0,145 & 0,058 & +++ & 0,047 \\
\hline $3 a$ & 9,03 & 0,031 & 0,108 & +++ & 0,043 \\
\hline $3 b$ & 9,26 & 0,096 & 0,113 & +++ & 0,045 \\
\hline $3 c$ & 8,86 & 0,103 & 0,220 & +++ & 0,044 \\
\hline $3 d$ & 9,10 & 0,929 & 0,226 & +++ & 0,045 \\
\hline $4 a$ & 8,79 & 0,906 & 0,237 & +++ & 0,047 \\
\hline $4 b$ & 8,65 & 0,034 & 0,119 & +++ & 0,048 \\
\hline $4 \mathrm{c}$ & 8,98 & 0,076 & 0,107 & +++ & 0,043 \\
\hline $4 d$ & 8,97 & 0,078 & 0,115 & +++ & 0,046 \\
\hline $5 a$ & 9,26 & 0,099 & 0,109 & +++ & 0,044 \\
\hline $5 b$ & 9,15 & 0,498 & 0,117 & +++ & 0,047 \\
\hline $6 a$ & 9,27 & 0,620 & 0,115 & +++ & 0,046 \\
\hline $6 b$ & 9,30 & 0,099 & 0,217 & +++ & 0,043 \\
\hline $6 \mathrm{c}$ & 9,78 & 1,460 & 0,114 & +++ & 0,046 \\
\hline $7 a$ & 9,08 & 1,001 & 0,228 & ++ & 0,046 \\
\hline $7 b$ & 9,15 & 0,088 & 0,119 & +++ & 0,048 \\
\hline $7 \mathrm{c}$ & 9,10 & 0,303 & 0,107 & + & 0,043 \\
\hline $12 \mathrm{a}$ & 9,27 & 1,071 & 0,487 & +++ & 0,049 \\
\hline $12 b$ & 9,33 & 0,832 & 0,427 & +++ & 0,043 \\
\hline
\end{tabular}

Tab. 1 Namerané hodnoty na trámcoch bez výstuže 


\begin{tabular}{|c|c|c|c|c|c|}
\hline $\begin{array}{c}\text { Ozn. } \\
\text { vzorky }\end{array}$ & $\mathrm{pH}[-]$ & $\begin{array}{c}\text { chloridy } \\
{[\%]}\end{array}$ & $\begin{array}{c}\text { dusičnany } \\
{[\%]}\end{array}$ & $\begin{array}{c}\text { sírany } \\
\text { semikvant. }\end{array}$ & $\begin{array}{c}\text { amónne } \\
\text { soli }[\%]\end{array}$ \\
\hline $8 \mathrm{a}$ & 10,21 & 0,135 & 0,122 & ++ & 0,049 \\
\hline $8 \mathrm{~b}$ & 9,75 & 0,066 & 0,106 & ++ & 0,043 \\
\hline $8 \mathrm{c}$ & 10,13 & 0,116 & 0,228 & +++ & 0,046 \\
\hline $9 \mathrm{a}$ & 10,01 & 0,120 & 0,248 & ++ & 0,050 \\
\hline $9 \mathrm{~b}$ & 10,65 & 0,121 & 0,107 & ++ & 0,043 \\
\hline $10 \mathrm{a}$ & 10,35 & 0,331 & 0,467 & +++ & 0,047 \\
\hline $10 \mathrm{~b}$ & 9,98 & 0,176 & 0,124 & ++ & 0,025 \\
\hline $10 \mathrm{c}$ & 9,45 & 0,133 & 0,109 & ++ & 0,022 \\
\hline $11 \mathrm{a}$ & 10,12 & 0,314 & 0,111 & ++ & 0,044 \\
\hline $11 \mathrm{~b}$ & 9,96 & 1,515 & 0,475 & ++ & 0,048 \\
\hline
\end{tabular}

Tab. 2 Namerané hodnoty na trámcoch s výstužou

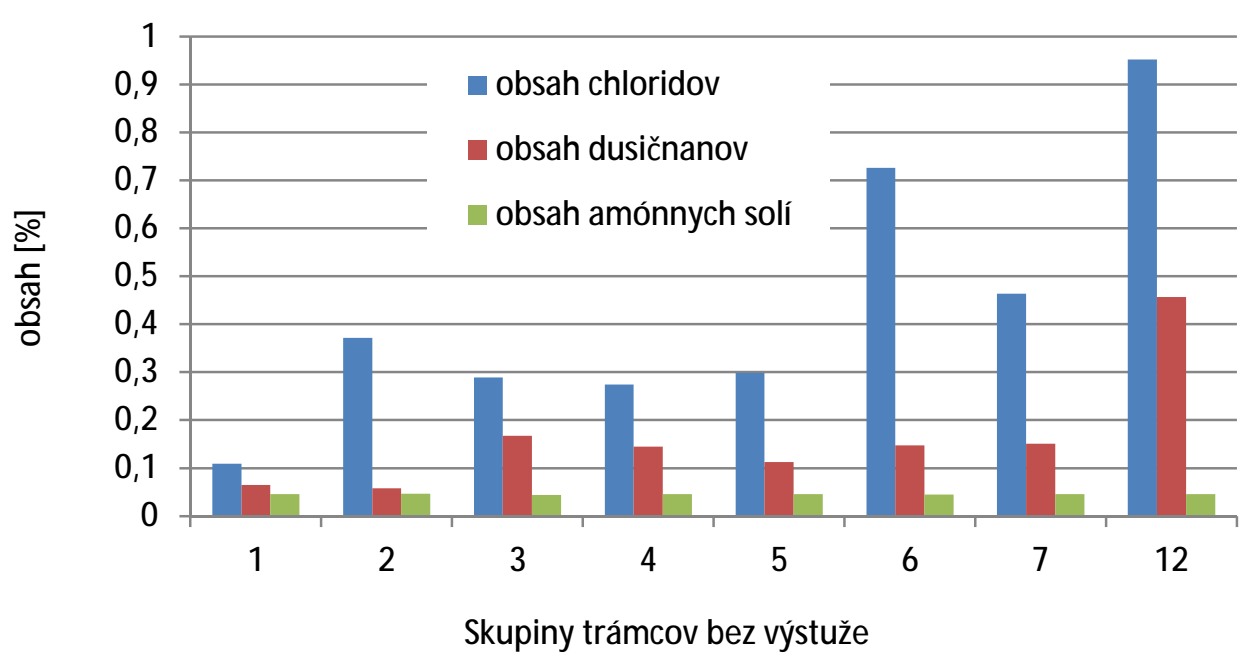

Obr. 3 Percentuálny obsah chemických látok - trámce bez výstuže

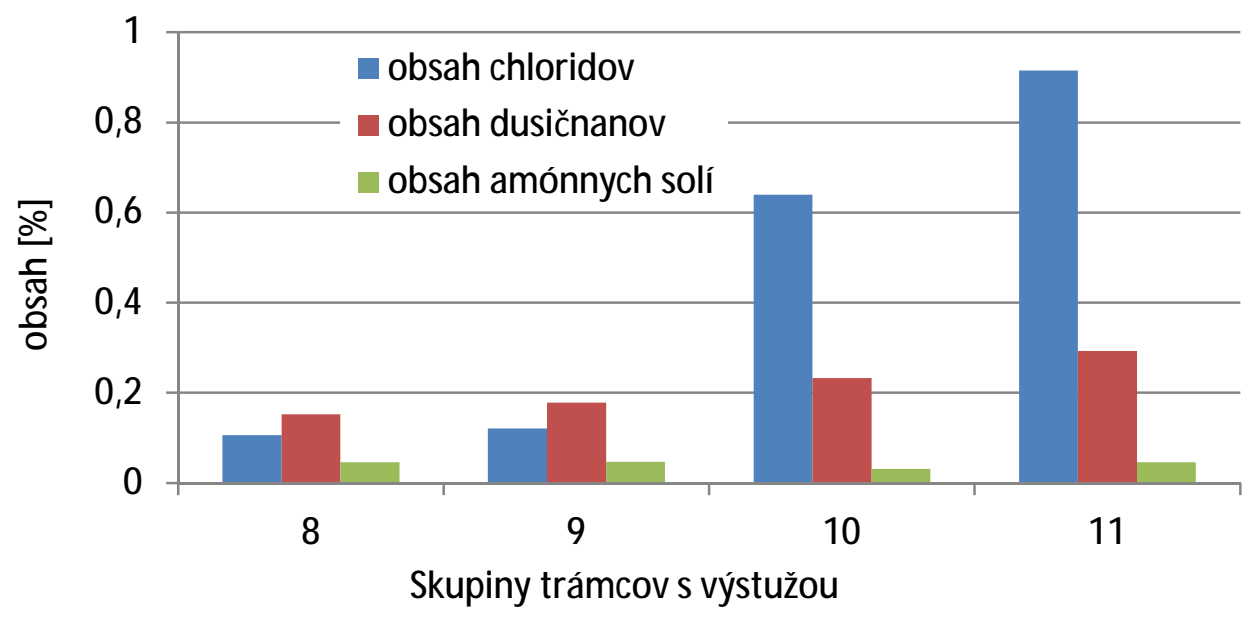

Obr. 4 Percentuálny obsah chemických látok - trámce s výstužou 


\section{VÝSLEDKY Z CHEMICKÉHO ROZBORU}

Z hl'adiska alkality (rozptyl pH 8,65 - 10,65) vzorky trámcov bez výstuže vykázali III. stupeň karbonatácie, len v dvoch skupinách sa preukázal II. stupeň karbonatácie (Tab. 1). U trámcov s výstužou bol preukázaný II. stupeň karbonatácie (Tab. 2). Fenolftaleinový test zaznamenal u trámcov bez výstuže aj u trámcov s výstužou rôznu hĺbku karbonatácie $(2-4 \mathrm{~mm})$, bol čiastočne pozitívny. U štyroch trámcov híbka karbonatácie presiahla kryciu vrstvu betónom $(17,18 \mathrm{~mm})$.

Z hl'adiska obsahu chloridových iónov sa ich množstvo posudzuje podl'a hodnoty požadovanej kategórie podl'a Tab. 10 uvedenej v norme [3] a to na základe percentuálnej hodnoty chloridových iónov vztiahnutej $\mathrm{k}$ hmotnosti cementu. Ako bolo uvedené v [1], pre betón s ocel'ovou výstužou je medzná hodnota $0,4 \% \mathrm{Cl}^{-}$a pre prostý betón $0,1 \% \mathrm{Cl}^{-}$. Priemerné hodnoty boli prepočítané a vztiahnuté $\mathrm{k}$ hmotnosti cementu a sú uvedené na Obr. 5 a 6 . Ked’že pôvodná receptúra betónovej zmesi nebola $\mathrm{k}$ dispozícii, pre účel vyhodnotenia merania boli zvolené tri hodnoty obsahu cementu $\mathrm{v}$ betóne a to minimum, maximum a priemer z obvyklých hodnôt, a teda uvažovalo sa s informatívnou hodnotou percentuálneho obsahu chloridových iónov vztiahnutou k hmotnosti cementu pre minimálne tri rôzne možné zámesi.

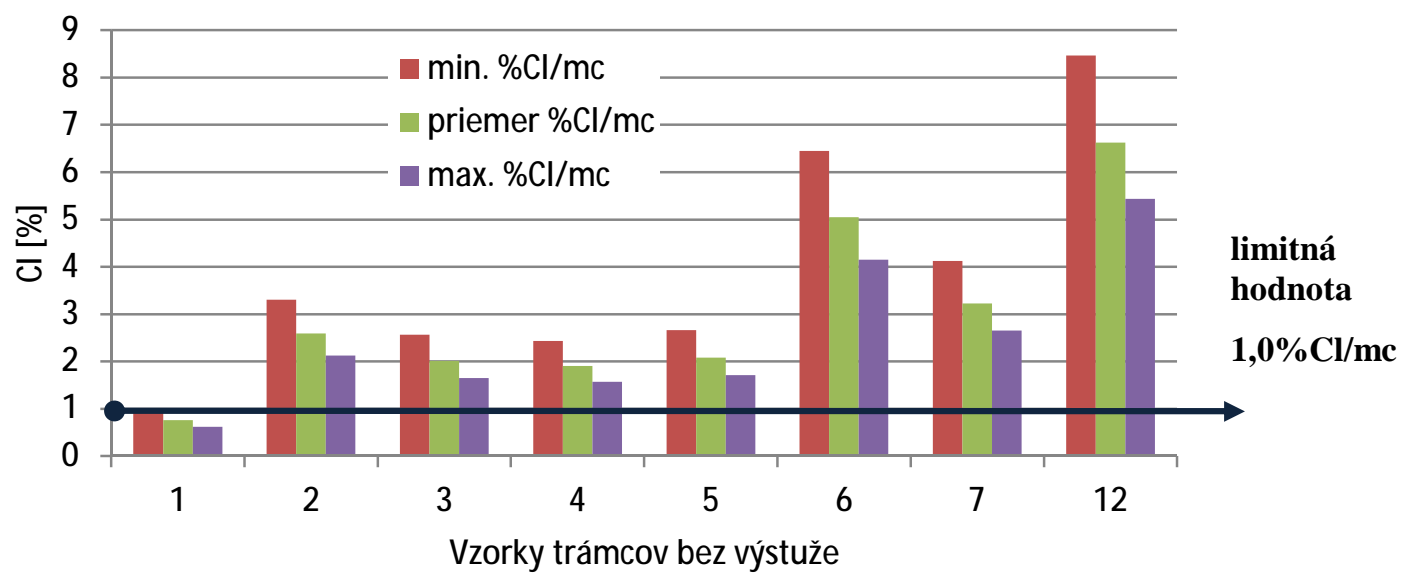

Obr. 5 Percentuálny obsah $\mathrm{Cl}^{-} \mathrm{k}$ hmotnosti cementu

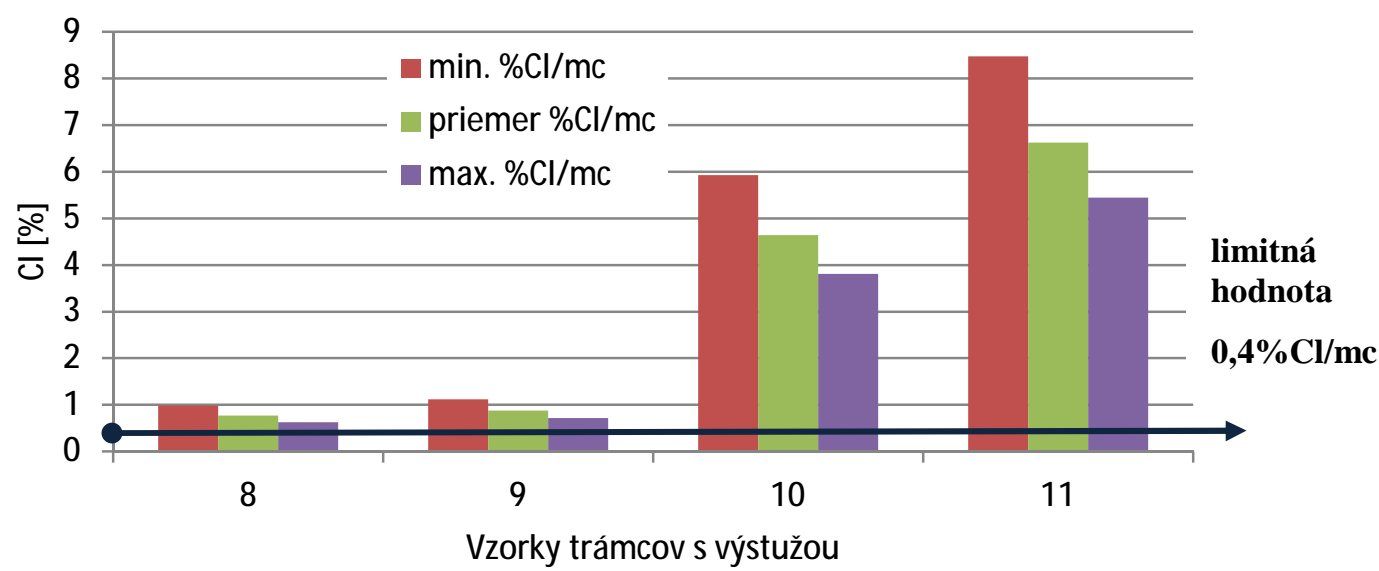

Obr. 6 Percentuálny obsah $\mathrm{Cl}^{-} \mathrm{k}$ hmotnosti cementu

Podl'a nameraných výsledkov pre betónové trámce jednoznačne vyplynulo, že obsah chloridových iónov prekračuje limitné hodnoty takmer u každej skupiny vzoriek aj pri maximálnej hodnote 
podielu množstva cementu. Je známe, že prítomnost' chloridových iónov v betóne nie je priaznivá skutočnost', ich vplyvom môže dôjst' k bodovej korózii výstuže.

Z hl'adiska koncentrácie síranových iónov u sledovaných betónových trámcov bola preukázaná pozitivita troma rôznymi stupňami a to slabá $(+)$, stredne silná $(++)$ a vel'mi silná $(+++)$ pozitivita. Tento výsledok sa javí ako logický, vzhl'adom na to, že trámce uložené vo svetlíkovom priestore svojou vzájomnou polohou (poukladané vedl'a seba a na sebe) mohli ovplyvnit' prenikanie iónov dovnútra.

Z hl'adiska koncentrácie dusičnanových iónov najnižšie koncentrácie boli preukázané u skupiny vzoriek bez výstuže, kde maximálna hodnota bola $0,487 \%\left(-\mathrm{NO}_{3}{ }^{-}\right)$. U vzoriek s výstužou bola maximálna hodnota $0,475 \%\left(-\mathrm{NO}_{3}{ }^{-}\right)$.

Z hl'adiska koncentrácie amónnych solí bola u skupiny trámcov bez výstuže maximálna hodnota $0,049 \%\left(-\mathrm{NH}_{4}{ }^{+}\right)$, u skupiny trámcov $\mathrm{s}$ výstužou bola maximálna hodnota $0,050 \%\left(-\mathrm{NH}_{4}{ }^{+}\right)$. $\mathrm{Z}$ nameraných hodnôt je vidiet', že pri tejto skúške hodnoty kolísali najmenej. Z hl'adiska ohrozenia konštrukcie uvedené percentuálne množstvá amónnych solí nepredstavujú akútnu hrozbu.

\section{ZÁVER}

Uvedené výsledky naznačujú, že v agresívnom prostredí je dôležité sledovat' obsah škodlivých látok v betónovej konštrukcii. Ich koncentrácia nemusí byt' nebezpečná, no na druhej strane môže dosiahnut' také percentá, ktoré sú už pre konštrukciu neprijatel’né. Chloridy spôsobujú nebezpečnú bodovú koróziu výstuže, pri ktorej dochádza k náhlemu hĺbkovému úbytku prierezovej plochy výstuže. Dusičnany spôsobujú postupnou chemickou reakciou výrazné zväčšenie objemu pevnej fázy, čo spôsobuje degradáciu štruktúry cementového kameňa. Síranová degradácia betónu súvisí so vznikom síranových minerálov, ktoré následne spôsobujú objemové zmeny vo vnútri štruktúry betónu. Z hl'adiska amónnych solí k degradácii cementového kameňa dochádza redukciou kyslíkových zlúčenín dusíka na amoniak.

Zaujímavým poznatkom, ktorý vyplynul z uvedených skúšok a zo skúšok publikovaných v [1] je skutočnost', že prenikanie sledovaných chemických látok neovplyvňuje vo vysokej miere pevnost' betónu. Obsah nameraných látok $\mathrm{v}$ zlomkoch stropných panelov a v trámcoch poukazuje na fakt, že v betóne s vyššou pevnotou (trámce) je možné namerat' vyššie koncentrácie látok než v betóne s nižšou pevnost'ou (stropné panely).

Záverom je možné skonštatovat', že pre betónové prvky určené do agresívneho prostredia treba dôsledne navrhovat' zloženie betónovej zmesi a to z hl'adiska špeciálnych prímesí, ktorými je možné eliminovat' prienik škodlivých látok dovnútra konštrukcie.

\section{Pod'akovanie}

Príspevok vznikol vd’aka podpore grantového projektu VEGA 1/0661/16 - „Správanie sa nosných prvkov z obyčajného a l'ahkého betónu ovplyvnených teplotou.“

\section{Použitá literatura}

[1] Priganc, Sergej; Hegedüsová, Iveta. Zhodnotenie stavu stropných panelov vagresívnom prostredí. Czech Journal of Civil Engineering. 2015/2. ISSN 2336-7148.

[2] Hegedüsová, Iveta; Priganc, Sergej. Analýza vlastností betónových panelov v agresívnom prostredí. TU - SvF 2015. ISBN 978-80-553-2312-1.

[3] STN EN 206-1.Betón. Čast’ 1: Špecifikácia, vlastnosti, výroba a zhoda. 2002. 